\title{
Reading De pace fidei Christologically: Nicholas of Cusa's Verbum Dialectic of Religious Concordance
}

\author{
Joshua Hollmann
}

In 2007, amidst the often polarizing tone of contemporary political and religious discourse regarding Islam and the West, various Muslim scholars from around the world jointly published A Common Word Between Us and You, an open and pacific letter addressed to Christian religious leaders worldwide. ${ }^{1}$ The preface to the letter proposes that since Muslims and Christians comprise more than half of the world's population, "[w]ithout peace and justice between these two religious communities, there can be no meaningful peace in the world," after which it goes on to emphasize that "the future of the world depends on peace between Muslims and Christians." 2 The letter also observes that the source of this peace is found in the revealed sources of both religions, ${ }^{3}$ for both the sacred texts of Christianity and Islam believe that God is one and affirm that followers of God should love their neighbours as themselves. In a similar vein, upon hearing the news of the fall of Constantinople to the Ottomans in 1453, the philosopher and prelate Nicholas of Cusa composed De pace fidei as a creative prayer for peace and a cogent plea for understanding the common religious concepts of Wisdom and the Word of God. ${ }^{4}$ For Cusanus,

1 The text of the Letter is found in Miroslav Volf, Ghazi bin Muhammad and Melissa Yarrington, eds., A Common Word: Muslims and Christians on Loving God and Neighbor (Grand Rapids, MI: Eerdmans, 2010), 28-50.

2 A Common Word, 28.

3 A Common Word, 28-29.

4 While this event is also referred to as the Ottoman conquest of Constantinople, for Cusanus and his Western Christian contemporaries this ominous occurrence marked more than merely a city's fall, but a full-scale catastrophe filled with foreboding of the impending religious and political conflict now exploding along the eastern front of European Christendom. For a classic overview of the early to mid-fifteenth-century conflict between the Ottoman and Christian powers see Franz Babinger, Mehmed the Conqueror and his Time, ed. William C. Hickman, trans. Ralph Manheim (Princeton, NJ: Bollingen Series XCVI, Princeton University Press, 1978). 
the source of peace between Christians and Muslims is found in the source of the cosmos: the Word and Wisdom of God, which the sacred texts of both Christianity and Islam affirm. ${ }^{5}$

Nicholas of Cusa's religious dialogue De pace fidei unfolds his theological view that the common Word and Wisdom between Christians and Muslims is Christ. In this essay we will consider a sapiential and Christological reading of De pace fidei. By reading De pace fidei through a dialectical Wisdom-Word theological lens, Cusanus's complex Christocentric universal and exclusivist approach to Islam will come into focus. Cusanus transmits the intrinsic tension between the exclusivity and inclusivity of orthodox Christology to address his understanding of the intricate relationship between Christianity and Islam. For Cusanus, the cosmic and incarnate Christ (the Verbum of God) forms the basis of an entire Christian philosophy to such a degree that the more he studies the cosmos, the more he sees Christ as the center of the coincidence of opposites wherein the many rites coincide within one religion. ${ }^{6}$ In order to examine the centrality of Christ in De pace fidei, we will begin with the text itself and first read the dialogue theologically through the locus of the Logos, or the Word of God (Verbum). This close read will then unfold through a contextualization of the Logos-Verbum Christology of De pace fidei within the greater Western Christian tradition. Finally, we will conclude with considering what Cusanus's philosophical and theological conversation on the Word and Wisdom of God might contribute to current dialogues between Christians and Muslims.

5 De pace fidei I, 1; h VII, ed. R. Klibansky and H. Bascour (1959); this edition incorporates Klibansky and Bascour's earlier edition, Nicolai de Cusa De Pace Fidei cum Epistula ad Ioannem de Segobia, Medieval and Renaissance Studies Supplement III (London: Warburg Institute, 1956), 1-90. James E. Biechler and H. Lawrence Bond reproduce the Latin text of $h$ with an English translation in Nicholas of Cusa on Interreligious Harmony: Text, Concordance and Translation of De Pace Fidei (Lewiston, NY: Edwin Mellen Press, 1990). Unless otherwise noted, I shall cite Biechler and Bond for De pace fidei's Latin text and English translation by chapter and paragraph number. Cribratio Alkorani (h VIII), alius prologus 15-16; I, 6, 42; I, 12, 58; I, 14; De pace fidei VI, 16; IX, 26; X, 27; XIX, 68.

6 F. Edward Cranz, "Saint Augustine and Nicholas of Cusa in the Tradition of Western Christian Thought," Speculum 28 (1953): 297-315, especially p. 298. Reprinted in Cranz, Nicholas of Cusa and the Renaissance, ed. Thomas M. Izbicki and Gerald Christianson (Aldershot: Variorum, 2000), 31-40. 


\section{Reading the Word and Wisdom of God in De pace fidei}

In 1446 Cusanus wrote a brief and bizarre treatise on the end of the world: Coniectura de ultimis diebus. ${ }^{7}$ In the work, Cusanus surmises that the world will end sometime between 1700 and $1734 .{ }^{8}$ While today this seems eccentric, in the context of the fifteenth century, conjectures on the ensuing apocalypse were far from strange. Cusanus's predictions are patterned on Augustine's eight epochs found in the conclusion of the City of God and the pervasive apocalyptic speculation of Joachim of Fiore. ${ }^{9}$ Fears of the impending end of the world would continue well after Cusanus with the likes of the Dominican Savonarola and the magisterial reformer Martin Luther, who was often depicted in his time as the prophetic second Elijah sent to proclaim the return of Christ. ${ }^{10}$ Cusanus also believed he lived in the latter days. Thus, in a letter to Jacob von Sirck from October 1453, after the fall of Constantinople, Cusanus writes: "I fear greatly that this violence may defeat us, for I see no possible uniting in resistance. I believe that we must address ourselves to God alone, though He will not hear us sinners."11 In De pace fidei, Cusanus claims that his prayer, at least mystically and metaphysically, has been answered. ${ }^{12}$

What is worth noting is not the conjectured end of the world, but rather, why Cusanus even forges ahead with his speculation. After all, Jesus of Nazareth had warned that no one knows the hour of his coming, which implied the condemnation of those vain seers who attempted to wrest knowledge of the future away from God. ${ }^{13}$ According to Cusanus, however, one may only endeavor to know in this lifetime the incomprehensible truth, even though in this world

Coniectura de ultimis diebus, in the Heidleberg Academy's edition, Nicolai de Cusa opera omnia, vol. IV, Opuscula I, ed. P. Wilpert (1959) (Hamburg: Felix Meiner Verlag, 1932ff.). Hereafter this edition will be cited as "h" followed by volume number. Coniectura de ultimis diebus, 127.

9 Augustine, De civitate Dei XXII, 30. On Joachim and Savanarola, see Bernard McGinn, trans., Apocalyptic Spirituality: Treatises and Letters of Lactantius, Adso of Montier-en-Der, Joachim of Fiore, the Franciscan Spirituals, Savonarola (New York: Paulist Press, 1979). On Luther as Elijah of the last times, see Andrew Cunningham, Andrew Ole, and Peter Grell, eds., The Four Horsemen of the Apocalypse: Religion, War, Famine and Death in Reformation Europe (Cambridge, uk: Cambridge University Press, 2000), 23-25. Tamed: Cusanus and the Traditions of Late Medieval Prophecy," Journal of Medieval History 9 (1983): 227-236.

11 Quoted in Karl Jaspers, Anselm and Nicholas of Cusa, ed. Hannah Arendt, trans. Ralph Manheim (New York: Harvest, 1966), 170.

12 De pace fidei I, 1.

13 Mark 13:32; Matthew 24:36. 
of conjectures, and echoing Augustine, we only know incomprehensible truth through symbolism that is infinitely distant from the truth itself. ${ }^{14}$ Or, as he says in his Apologia doctae ignorantiae, true theology remains hidden in sacred Scripture, the very Word of God..$^{15}$ Therefore, Cusanus argues that he speculates because he claims to know only this Word of God, namely, the preincarnate Logos and the person of Christ. ${ }^{16}$ According to the dialogical structure of Cusanus's tract on religious concordance, De pace fidei, it is in Christ that the metaphysical and the physical coincide. According to Cusanus, concordance is the principle by which there is harmony between the one and the many. ${ }^{17}$ De pace fidei identifies the Word of God as Logos and the incarnate interlocutor between the one (God) and the many (representatives of the religion of the world)..$^{18}$ Indeed, for Cusanus, Christ is the very wisdom of God. ${ }^{19}$ Therefore, this Divine Word-Wisdom is the ground for speculating about time and eternity, as well as the basis and starting point for his conciliatory and complicated approach to Islam in De pace fidei and Cribratio Alkorani. ${ }^{20}$ Furthermore, according to Cusanus, every human assertion on what is true is conjecture, yet when connected to Christ - the hypostatic union of God-Man, the infinite and finite, the very way and truth - these conjectures become closer to hidden wisdom. ${ }^{21}$ In De pace fidei and the prologue to the Cribratio Alkorani, this truth is none other than the Word and Wisdom of God, in whom all things are unfolded and from whom they are enfolded. ${ }^{22}$

In De pace fidei, Cusanus identifies Wisdom as the pre-incarnate Logos and the incarnate Christ through whom all things are unfolded and enfolded, and thereby knowable. ${ }^{23}$ Wisdom is therefore made known in the Word of God (Verbum). This Wisdom may be read in the reasonable order and symmetry of creation. ${ }^{24}$ In addition, this Wisdom became incarnate in Christ, who further and supremely reveals the concordance of 'religio una in rituum varietate. 25 Thus, in the Logos and in Christ, this Wisdom is recognizable and attainable

14 Coniectura de ultimis diebus, 123. Cf., De pace fidei XVI, 55; Augustine, De doctrina Christiana, I, 4-5.

15 Apologia doctae ignorantiae (h II), 4.

16 Coniectura de ultimis diebus, 124.

17 De concordantia catholica (h XIV) I, 1, 4.

18 De pace fidei III, 8; IV, 10; X, 27.

19 Coniectura de ultimis diebus, 124; 1 Corinthians 2:2; Colossians 2:3.

20 De pace fidei III, 9; Cribratio Alkorani prologus, 8-10.

21 De Coniecturis (h III) I, prologus; De pace fidei II, 7; John 14:6.

22 De pace fidei II, 7; III, 8; Cribratio Alkorani prologus, 8-10; Idiota de sapientia (h V) I, 21-23.

23 De pace fidei II, 7; VI, 17.

24 De pace fidei IX, 26.

25 De pace fidei I, 6. 
by Divine illumination, by grace. In De pace fidei, after Cusanus proposes that there remains an infinite gap between human and divine wisdom, he goes on to discuss how there is only one Christ, "in whom human nature is united with the divine nature in supposited unity."26 In Christ, the divine intellect is united to the human intellect. However, in order to reassure Muslims, Cusanus affirms that in this union the unity of God is preserved. For Cusanus, not only are the Divine and human intellects united in the Word, but De pace fide $i$ also holds that human nature is united with the divine nature in the incarnate Christ. He is, as Cusanus writes, "the face of all peoples and the highest Messiah and Christ, as the Arabs and Jews call Christ."27 As the face of all peoples, Christ's face is especially turned toward the great prophets of the 'religio una in rituum varietate. ${ }^{28}$ As demonstrated in the preface to Cusanus's exposition on the Qur'an, the Cribratio Alkorani, this includes the Prophet Mohammed ${ }^{29}$ De pace fidei proposes a global Pentecost - a reversal of the confusion of Babelthat entails the dialectical concordance of discordant religious languages in the one Word of God. The Wisdom and the Word, words and the Word, signs and that which is signified in everything: for the Word and Wisdom of God, according to Cusanus, flows through all ranks of being, and encompasses all things. ${ }^{30}$

Cusanus's dialogue proper of De pace fidei begins with the Wisdom of God, which leads straightaway to the synonymous Word of God. From there, the complexities of unity and plurality and Trinity in unity are discussed, followed by an exposition of the tension between finite and infinite in the incarnation of the Word of God. Finally, resurrection, paradise, faith, tradition, and rites are explored. Together, these propositions or 'storeys,' from natural reason to divine revelation, further expand one by one the foundational element or building block of 'religio una in rituum varietate. ${ }^{31}$ What joins these levels of understanding together with peace is the Wisdom or Word of God. For it is the Word (Verbum) of God who builds, initiates, furthers, clarifies, and finally ratifies the religious discussion. It is, after all, the Word's house of religious peace. Sapientia is unique and through it the cosmos came to be. ${ }^{32}$ Furthermore, towards the beginning of De pace fidei, sapientia is clearly identified as the

\footnotetext{
26 De pace fidei XII, 39; trans. Biechler and Bond, p. 37.

27 De pace fidei XIII, 43: "in illo scilicet qui est facies omnium gentium et altissimus Messias est Christus, prout nominant Christum Arabes et Iudaei"; trans. Biechler and Bond, p. 40.

28 De pace fidei I, 6.

29 De pace fidei I, 6; Cribratio Alkorani, alius prologus, 13-15.

$30 \quad$ De pace fidei II, 7; De concordantia catholica I, 2, 10.

31 De pace fidei I, 6.

32 De pace fidei IV, 11: "Non potest esse nisi una sapientia."
} 
eternal and generating Word of God. ${ }^{33}$ And the cosmos is, after all —at least for Cusanus and his western Christian forbears and contemporaries- the created domain of the Word and Wisdom of God. ${ }^{34}$ Ultimately, the Cusan thesis 'religio una in rituum varietate' flows from the Wisdom and Word of God, and moves dialectically and hierarchically through the cosmos. ${ }^{35}$

According to Cusanus and his medieval predecessors, the world is created in Wisdom, by Wisdom, and for Wisdom. For Christians, this powerful Wisdom of God is further identified with the person and work of Jesus Christ (who, according to orthodox Christian doctrine, is in his twofold nature both Creator and creature). ${ }^{36}$ Thus, the cosmos is rational, and can (and should) be 'read' by the senses and deciphered in the mind and in the harmonious pursuit of being made wise unto the peace of faith. ${ }^{37}$ Cusanus posits that Divine Wisdom may be 'read' in the mind, although owing to the ignorance of sin, it is difficult although not impossible to decipher. ${ }^{38}$ As Book I of De docta ignorantia shows, the cosmos may be read in geometry and mathematics. It may also be read in

33 De pace fidei V, 15: Sapientia igitur est aeternitas"; De pace fidei VI, 17: the Arab (as one well acquainted with wisdom in the Arab philosophical tradition) addresses the Word (Verbum), "Tu es sapientia, quia Verbum Dei."

34 Cf., Augustine, Confessions, XII, xi; XII, xix. Augustine seeks the eternal house of God in the heavens of heavens. This house does not experience the vicissitudes of time. It is the abode of peace and harmony, the goal of the pilgrim. In De pace fidei, Cusanus sets his council in the heaven of reason and the court of God (i.e., the house of reason and house or domos of God, the place of religious peace and the goal of the pilgrim still struggling in a world torn apart by religious violence). In this heavenly house, the 'Trinity' of memory, understanding, and will is one (Cf., Augustine, De Trinitate $\mathrm{X}$, iv). For the religious representatives of the world become one in peaceful accord (not only with each other, but also with angels and the Word of God and the saints). They understand 'religio una in rituum varietate' and remember what has transpired in the heaven or altitude of reason within (the mind's road to God) in order to will it to become reality in the world without (senses) and below (earth). Their actions resemble and participate in the Trinity (by the economy of the Wisdom and Word of God) in memory, understanding, will, and the concord of God's undivided peace.

35 De pace fidei I, 6.

$36 \quad 1$ Corinthians 1:24.

37 Cf., 2 Timothy 3:15. For Cusanus and St. Paul, Christ, the ultimate Word and Wisdom to whom Scripture testifies, makes seekers of truth and concord wise unto the peace of reconciliation with God and one another, and, hence, harmony between heaven and earth.

$3^{8}$ De pace fidei I, 3: "excitatus admiratione eorum quae sensu attingit, posit aliquando ad te omnium creatorem oculos mentis attollere et tibe caritate summa reuniri, et sic demum ad ortum suum cum fructu redire." De pace fidei I, 4: "Ex quo factum est, quod pauci ex omnibus tantum otii habent, ut propria utentes arbitrii libertate ad sui notitiam pergere queant." Cf., Aquinas, Summa Theologice, Ia, 1, 1: “Quia veritas de Deo per rationem 
Holy Scripture and in the Qur'an. ${ }^{39}$ As De pace fidei illustrates, it may also be read in the writings of the ancient Hellenic philosophers. ${ }^{40}$ The ultimate way in which God makes his Wisdom and the way to happiness and immortality known is through the Incarnation of the Word made flesh - the Word beyond words, the sure via of knowledge, beatitude, and peace. ${ }^{41}$ Thus, in De pace fidei, drastic times (such as the fall of Constantinople) call for drastic measures: the Word and Wisdom of God reason face-to-face with the religious leaders of the world in order to establish an enduring peace of faith..$^{42}$ To realize this peace and avert the maelstrom of religious violence, Wisdom and the Word make opposites known (the many rites and the many adherents of those rites) in relation to the One (both one God and the one religion).

At the outset of De pace fidei, Cusanus identifies truth as the Word of God in which all things are enfolded (complicantur) and through which all things are unfolded (explicantur). ${ }^{43}$ This Truth, this Word and Wisdom, speaks words of truth and wisdom, which in turn reveal-point by point in an unfolding manner - the concordance of one single religion in a variety of rites. Cusanus affirms that "between 'contracted wisdom,' i.e., human wisdom, and wisdom per se, which is divine and maximum and infinite, there always remains infinite distance." 44 Thereby, in this confusing world of conjectures and similitudes, Cusanus's conception of the incarnate Word in De pace fidei utters in dialogical form the path to the signified one religion by means of a variety of signs. ${ }^{45}$ For Cusanus, the human nature of Christ united to the Divine Word leads the imagined wise readers of De pace fidei to the final happiness of religious concord. Cusanus's hermeneutic of Wisdom and the Word through signs and things signified as flowing from and returning to the Word of God as

investigata a paucis, et per longum tempus, et cum admixtione multorum errorum homini proveniret."

39 Cribratio Alkorani, alius prologus, 16.

40 De pace fidei XIX, 68.

41 De pace fidei II, 7; De pace fidei XIV, 49.

42 De pace fidei III, 8: "indiget humana natura crebra visitatione, ut fallaciae quae plurimum sunt circa Verbum tuum extirpentur et sic veritas continue elucescat."

43 De pace fidei II, 7: "Quae quidem veritas intellectum pascens non est nisi Verbum ipsum, in quo complicantur omnia et per quod omnia explicantur."

44 De pace fidei XII, 36 ; trans. Biechler and Bond, p. 36 .

45 De pace fidei II, 7. The Verbum has put on human nature so that humans may attain to the truth of one religion in the variety of rites and eternal felicity: "[Verbum] et quod humanam induit naturam, ut quilibet homo secundum electionem liberi arbitrii in sua humana natura, in homine illo qui et Verbum, immortale veritatis pabulum se assequi posse non dubitaret." Cf., De pace fidei III, 8; De coniecturis I, 2. 
dialogical dialectic of peace. ${ }^{46}$ This Word speaks words in the dialogue form of De pace fidei, and enlightens Cusanus to write words of religious concordance. As his Idiota de sapientia et de mente and De veneratione sapientiae reveal, the master of learned ignorance spent his scholarly and spiritual life searching for the Wisdom and "the peace of God, which surpasses all understanding."47 According to Cusanus, the mysterious and cosmically generating Wisdom cries out in the streets to be welcomed readily by laymen (idiota) and even by the proponent of 'the barbarous ineptitudes' of learned ignorance-Cusanus himself. ${ }^{48}$ And yet, this wisdom leads to greater insight: the final vision of God, whereupon "God grants that He be made visible to us without enigma." ${ }^{49}$

\section{Reading the Christology of De pace fidei within the Christian Tradition}

Cusanus spent his life hunting for this known-yet unknown-wisdom. As Karl Jaspers notes, Cusanus is the only major thinker of his century who did not belong to any school or found a school..$^{50} \mathrm{He}$ was somewhat of a metaphysical loner, much like the great scholars of the ninth century, such as John Scotus Eriugena. And yet, his ideas still remain and he sometimes seems strangely at home in our multi-religious age. His individual quest for the plenitude of wisdom uncovers a new Christocentric and communal understanding of religious peace. Cusanus's Christocentric ideas on religious peace in De pace fidei are deeply rooted in ancient Hellenic thought and the Bible-wisdom as found in both reason and revelation. The Christology of De pace fidei is Johannine. Indeed, for Cusanus as for the author of the Gospel according to John, there is nothing beyond the horizon of the Word (Logos-Verbum)..$^{51}$ Cusanus's cosmic Christology of De pace fidei also transmits the tradition of ancient Hebraic wisdom from the Book of Proverbs, as well as the Hellenic Lady Philosophy

46 Augustine, De doctrina Christiana, I, 4-10. Cf., Hans-Georg Gadamer, Truth and Method, trans. Joel Weinsheimer and Donald G. Marshall, 2nd ed. (London: Continuum, 2004), $435-436$.

47 Philippians $4: 7$ NRSV.

48 Proverbs 8-9; De docta ignorantia, prologus; trans. Biechler and Bond, 87.

49 Idiota de sapientia (h V) II, 47: "sine quo in hoc mundo Dei visio esse nequit, quousque concesserit Deus, ut absque aenigmate nobis visibilis reddatur"; translation in Nicholas of Cusa, The Layman on Wisdom and the Mind, trans. M. L. Führer (Ottawa: Dovehouse, 1989), 49 .

$50 \quad$ Jaspers, Anselm and Nicholas of Cusa, 164.

$5^{1} \quad$ John 1:1-18; De pace fidei II, 7 . 
of Boethius's Consolation..$^{2}$ As in the Gospel of John, there are two dialectical aspects to Cusanus's Christological approach to Islam: universalism and exclusivism. ${ }^{53}$ As a late-medieval churchman, Cusanus inherited both the universalist and exclusivist Christologies of the ecumenical councils of Nicaea (325) and Chalcedon (451). The former included the fundamental tenet of orthodox Christian faith that the Logos is the same substance as God (homoousios, unius substantiae cum patre), through whom all things came to be, while the latter incorporated Pope Leo's famous Tome, which stated that the incarnate Logos, the Son of God, is one person with two natures (divine and human, 'unitatem personae in utraque natura'). ${ }^{54}$ Leo's Tome, serving as prolegomena to the Cribratio Alkorani, weaves together the two threads of universality and exclusivity into the one tapestry of Christ. For these purposes, Leo quotes Proverbs and the Gospel of John: "As Wisdom built a house for herself, the Word was made flesh and dwelt among us." This Word becomes flesh so that the proper character of both natures can be maintained while coming together in a single person..$^{55}$

While Cusanus's sapiential ideas of religious concordance are rooted in reason and revelation, in conciliar and constructive thought, they are also formulated within the catholic historical theological tradition. Another angle for viewing Cusanus's dialectic of reason and revelation, the exclusivity and universality of his Christology as evidenced in De pace fidei, sees Cusanus inheriting both the catholic exclusivity as represented by the late medieval reading of the third-century bishop Cyprian of Carthage, as well as the mystical inclusivity of an Augustian conception of religion. It was Cyprian who famously

52 Proverbs 8-9; Boethius, Consolation of Philosophy I, 1.

53 John 1:1-18; 14:6. On universalist Verbum Christology, see De pace fidei VI, 17-18. On exclusivist Christology, see De pace fidei XI, 30-35.

54 Leo's Tome is a famous letter sent by Pope Leo I, 'the Great,' to the Council of Chalcedon (451) on Christology. It is generally accepted as classic formulation of Christian orthodoxy on the person of Christ. Cribratio Alkorani, preface 1. Council of Nicea, Expositio fidei CCCXVIII partum in Norman P. Tanner, ed., Decrees of the Ecumenical Councils, 2 vols. (London: Sheed \& Ward, 1990), vol. 1, 5. Leo's Tome, Epistula Papae Leonis in Tanner, Decrees of the Ecumenical Councils, vol. 1, 80.

Cribratio Alkorani, preface 1, citing Pio Secundo Universalis Christianorum Ecclesiae Summo Sactissimoque Pontifici. Leo's Tome in Tanner, Decrees, vol. 1, 78: “Fecuditatem virginis spiritus sanctus dedit, veritas autem corporis sumpta de corpore est, est aedificante sibi sapientia domum verbum caro factum est habitavit in nobis, noc est in ea carne quam sumpsit ex homine et quam spiritu vitae rationalis antimavit. Salva igitur proprietate utriusque naturae et in unam coeunte personam." Cf., Proverbs 9:1; John 1:14. 
stated: "Outside the church, there is no salvation (extra ecclesiam nulla salus)."56 Cyprian, much like Cusanus, was adamant in maintaining the unity of the catholic church, especially in the face of heresies and schisms threatening to rend concordance asunder. Thus, Cusanus appeals to a late medieval reading of Cyprian. According to Cusanus, the source of this unity is Christ, as represented on earth by the bishops and preeminently the Bishop of Rome. ${ }^{57}$ In $D e$ concordantia catholica, Cusanus notes that from ancient tradition there is only one cathedra and one rule established in hierarchical gradations. ${ }^{58}$ Similarly, Cyprian had asked rhetorically: "If a man does not hold fast to this oneness of the Church, does he imagine that he still holds the faith?"59 The precursor to the Cribratio Alkorani, turning us back again to Leo's Tome, is evidence that Cusanus considers Islam to be an ancient Nestorian heresy now continued as a sect. In De pace fidei, moreover, Cusanus conceives that schisms exist because many longstanding customs confuse rites for religion and eventually become lost in the diffuse manifestations of the one unity of religion. ${ }^{60}$ Therefore, the goal of De pace fidei is the eradication of global religious schism through conciliar and Christocentric dialogue. Furthermore, for Cyprian and Cusanus, "the Church forms a unity, however far she spreads and multiplies by the progeny of her fecundity." 61 And, for Cyprian, "[y]ou cannot have God for your Father

56 Cyprian of Carthage, Epistle LXXII, Ad Jubajanum de haereticis baptizandis, section 21: "Salus extra ecclesiam non est." See also how Cyprian is quoted by Pope Boniface VIII in the high water mark of the medieval papacy, Unam sanctam (1302).

57 Cyprian, De Ecclesiae catholicae unitate, 4-6. On the primacy of the Roman chair, see 4 (first edition of the treatise, note the two versions of the treatise on this pivotal section): "Super illum aedificat ecclesiam et illi pascendas oves mandat et, quamvis apostolis omnibus parem tribuat potestatemm unam tamen cathedram constituit et unitatis originem adque rationem sua auctoritate disposuit. Hoc erant utique et ceteri quod fuit Petrus, sed primatus Petro datur et una ecclesia et cathedra una monstratur."

$5^{8}$ De concordantia catholica I, VI, 36 : "Unde sicut episcopatus unus, ita una cathedra et una praesidentia gradualiter et hierarchiæ constituta."

59 Cyprian, De Ecclesiae catholicae unitate, 4 (2nd edition of the treatise): "Hanc ecclesiae unitatem qui non tenet, tenere se fidem credit?" For an English translation of the above, see Cyprian, De Lapsis and De Ecclesiae Catholicae Unitate, text and trans. Maurice Bévenot (London: Oxford University Press, 1971), 64-65.

6 De pace fidei I, 4 .

61 Cyprian, De Ecclesiae Catholicae Unitate, 5 (2nd edition of the treatise); trans. Bévenot, 65 : "Ecclesia una est quae in multitudinem latius incremento fecunditatis extenditur." Cf., $D e$ concordantia catholica I, I, 7; I, VI, 35; I, VIII, 43; I, XIV, 58; XV, 60; II, XVII, 141; II, XXVI, 209; II, XXXIV, 256. Consider also the global scope of the church or one religion in the variety of rites in De pace fidei. 
if you no longer have the Church for your mother."62 In the pivotal and foundational beginning of De concordantia catholica, on the Word of God, Cusanus cites this very same passage of Cyprian. ${ }^{63}$ There he writes that "concordance is highest truth itself," and after citing Cyprian, describes how those in the church are united to Christ. ${ }^{64}$ Accordingly, Cusanus writes:

Christ is the way, the truth, and the life, and the head of all creatures, the husband or spouse of the church, which is constituted in a concordance of all rational creatures - with him as the One, and among themselves, the many—in various [hierarchical] gradations. ${ }^{65}$

Cusanus, like Cyprian before him, clearly connects the unity of the church to the person of Christ. Yet, in a distinctly innovative turn, he moves beyond the confines of the catholic church in De pace fidei to include Judaism, Islam, and Hinduism, through a hierarchical gradation of one religion in the variety of rites. These religious rites are coincidently and consubstantially joined as one concordance of peace through the dialogical Verbum and by way of his hierarchical emissaries, most notably, the apostle and first pope, Peter. ${ }^{66}$ According to Cusanus, it is the Verbum of God that reveals the religious concordance of one religion in the variety of rites dialectically, one theological proposition after another, until the conversation continues onto the crucial intricacies of Christology with Peter, who takes his turn in the dialogue of De pace fidei after Christ, "the eternal pontiff." 67

The Christology of De pace fidei is exclusive in its appeal to ancient formularies of Christian thought, but it is also inclusive and universal in its conception of religious concordance through the Word of God. Cusanus brings

62 Cyprian, De Ecclesiae Catholicae Unitate 6; trans. Bévenot, 66: "Habere iam non potest Deum patrem qui ecclesiam non habet matrem." Cf., De concordantia catholica I, I, 7 . Cited by Cusanus in the context of arguing for the primacy of I, VI, 35 .

63 De concordantia catholica I, I, 7.

64 De concordantia catholica I, I, 7.

65 De concordantia catholica I, I, 8; Paul E. Sigmund, trans., The Catholic Concordance (Cambridge: Cambridge University Press, 2003), 7. Cf., John 14:6. "Unde haec est summa dicendorum, quod Christus est via, veritas et vita et omnium creaturarum caput, maritus sive sponsus ecclesiae, llquaell per concordantiam creaturarum omnium rationabilium ad eum unum et inter se plurium constituitur secundum varias graduationes."

66 Peter leads the conversation of De pace fidei on Christology proper from chapters XI to XVI. Cf. Mark 8:29 where Christ asks Peter, "But who do you say that I am?" (NRSv). The question of who Christ is in De pace fidei is answered by Peter.

67 De concordantia catholica I, III, 13; trans. Sigmund, Catholic Concordance, 11. 
Neoplatonic philosophy into the service of catholic truth. For Cusanus, the hypostatic Word of God has its own exclusive substantial reality (contra modalism), and the Word universally flows through all things. Yet in De pace fidei, Cusanus aims to hold the universal and the exclusive together in his Christocentric approach to Islam. According to the prologue to the dialogue, through the art of contemplation he sees all this as the complete metaphysic of religious peace. God reveals the truth of one religion in the variety of rites. To echo Anselm of Canterbury, Cusanus sees and believes in order to understand the religious concordance of the Word of God. ${ }^{68}$ For Cusanus, Athens coincides with Jerusalem, in other words, the City of God as reason coincides with revelation to form one universal metaphysic of unity. Unlike Tertullian, however, Athens has everything to do with Jerusalem. ${ }^{69}$ Thus the dialogue begins in a metaphorical Athens, as signified by the Greek interlocutor, and concludes in the heavenly and earthly Jerusalem, where the unity of the peace of faith is pronounced as concurrent with ancient philosophy and Christian theology as one complete religious metaphysic. ${ }^{70}$

In De pace fidei, Cusanus dialectically and hierarchically holds together Athens and Jerusalem, reason and revelation, universalist and exclusivist outlooks, conciliar-catholic tradition and the pragmatic concerns of the present, all of which are centered in the cosmic and incarnate Christ. ${ }^{71}$ Another way of reviewing the two aspects of the universalist and exclusivist polarities of Cusanus's Christology focuses on his love of cataphatic and apophatic theology (as the master of learned ignorance). Cusanus begins the theological dialogue of De pace fidei with the Word as Truth and Wisdom, which embraces all things and is embraced by the philosophers. ${ }^{72}$ What humanity can say about God arises, then, (to allude to Dionysius the Areopagite) from the sum total of creation, but also, more precisely, from the sum total of religious rites. Cusanus believed that Wisdom made the world. Therefore, this cosmos is rationally knowable by all those seeking truth. Yet for Cusanus, all human assertions are but conjectures. Thus, the revelation of Wisdom made flesh is required in order to clarify confusions of rites with religion, or creation with the creator.

68 Anselm of Canterbury, Proslogion I, 1.

69 Tertullian, Prescription of the Heretics, 7.

70 De pace fidei IV; XIX, 68. On the primacy of Jerusalem as city of ecclesiastical and hierarchical synthesis, see De concordantia catholica XVI, 64 .

71 For a succinct overview of the universalist and exclusivist impulses of Christology, see Richard Viladesau and Mark Massa, eds., World Religions: A Sourcebook for Students of Christian Theology (New York: Paulist Press, 1994), 9-16.

72 De pace fidei II, 7; IV-VI. 
Cataphatic verbosity may lend itself to catastrophic confusion of words for the Word. The names for God "are fittingly derived from the sum total of creation,"73 and indeed, according to Dionysius, theologians praise God "by every nameand as the Nameless One."74 Thus, since God created all things, everything shares in beauty and is good. ${ }^{75}$

Dionysius's hierarch, the Word of God, appears as the central character of Cusanus's religious dialogue and as the foundation of his conception of one religion in the variety of rites. ${ }^{76}$ We therefore see a Dionysian, cataphatic (universalist) side to Christology: the Word embraces all things. Even so, this Word speaks for the hidden God who remains ever unknown and unknowable. ${ }^{77}$ Within this cataphatic sum total of creation, some rites are better than others, and some theological, dialogical points are higher than others. According to Dionysius and Aquinas, hierarchy operates from the lower to the higher by way of the middle-according to the so-called 'lex divinitatis. ${ }^{78}$ As Dionysius maintains, theologians discuss hierarchies in order to make known the ranks of heaven, but also to reveal the mystery of God. ${ }^{79}$ Thus, "[ $\left.t\right]$ he most evident idea in Christian theology, namely, the sacred Incarnation of Jesus for our sakes, is something which cannot be enclosed in words nor grasped by any mind." ${ }^{80}$ What can be grasped with more certainty is that Christology and the sacred incarnation of the preexistent Logos come to the fore in Cusanus's conversation with Islam. Moreover this Christological approach to Islam in De pace fidei is not only conciliar and catholic, but also hierarchical and dialectical. Christ mediates between the lower to the higher, between discursive rites and speculative religious concordance. The angels receive the truth of one religion in the variety of rites through intellectual purity, while humanity receives it by means of sensible signs. ${ }^{81}$ It is the Word, moreover, that mediates this

73 De divinis nominibus I, 7, 597A, p. 56. Translation by Colm Luibheid, Pseudo-Dionysius: The Complete Works (New York: Paulist Press, 1987). Cf., De pace fidei VII, 21: "Nam nomina quae Deo attribuuntur, sumuntur a creaturis, cum ipse sit in se ineffabilis et super omne quod nominari aut dici posset."

74 De divinis nominibus I, 6, 596A, p. 54; trans. Luibheid.

75 De coelesti hierarchia II, $3,141 \mathrm{C}$.

$7^{6}$ De ecclesiatica hierarchia II, 1, 393A.

77 De pace fidei I, 4-5; II, 7 .

78 Ephesians 1:20-21; De coelesti hierarchia III, 1, 164D; Pope Boniface VIII, Unam sanctam; Aquinas, Summa Theologice Ia., 108, 1; Summa Theologice Ia., 108, 6.

79 De coelesti hierarchia II, 5, 144C.

8 o De divinis nominibus II, 9, 648A, p. 65; trans. Luibheid.

81 De coelesti hierarchia I, 1-3, 120B-124A; Aquinas, Summa Theologice Ia, 108, 1; De pace fidei I, 2 ; XVI, 55 . 
concordance from the angels (higher) to humanity (lower). The dialogue proper of De pace fidei begins more generally (with concepts such as Divine Wisdom and Word), and then by the end of the imagined conversation moves to touch upon all forms of diverse rites and practices. Yet the dialogue concludes with the stillness of peace, which surpasses all human power of utterance. Final realization of religious peace remains mystical and speculative, beyond this world, the theoria of vision, and is envisioned in the dialogue to be the New Jerusalem. The dialogue is bookended as Cusanus's own recollection of an intellectual vision and as the culmination of the contemplation of religious concordance. ${ }^{82}$ Cusanus attempts to unfold the enigmatic aspect of Wisdom and the Word from memory in the flux of conjecture as if peering through a dark mirror. ${ }^{83}$ What does shine forth in De pace fidei is Christ as both creative cataphatic revealer of the concordance of every conceivable religious rite, and as narrow apophatic mystical way to unity beyond the finite dialogical conundrum, "where a sentence has both a beginning and an ending." 4

Cusanus's Christocentric synthesis of religious concordance is formulated through the concepts and categories of Christian theology, Christian Neoplatonic mysticism, and Greek philosophy. Cusanus's frequent use of the word religio in De pace fidei echoes ancient Hellenic ideas, but also Augustine, the great harmonizer of Neoplatonism and Christianity. ${ }^{85}$ In De vera religione, Augustine explores the universal nature of religio, but also moves beyond the dialectic of inclusivity and exclusivity to discover the contemplative within the Christian faith. Cusanus had read Devera religione, and cites the work in Depace fidei. ${ }^{86}$ There, Augustine argues that the good and blessed life "is to be found entirely in the true religion wherein one God is worshipped and acknowledged with purest piety." 87 Furthermore, vestiges of this true religion are to be found everywhere through the agency and providence of Divine Wisdom. ${ }^{88}$ Even so, Augustine summons lovers of wisdom to "turn to God so that we may deserve to be illumined by his Word, the true light." 89 This path is open to everyone.

\footnotetext{
82 De pace fidei I, 1; XIX, 68.

83 De pace fidei $\mathrm{I}, 1$.

84 Augustine, Confessions IX, x (24); English translation by Henry Chadwick (Oxford: Oxford University Press, 1998), 171.

85 Cusanus employs religio or its declensions 27 times throughout De pace fidei.

86 De pace fidei II, 7; De vera religione 39. See critical apparatus of h VII, 8.

87 Augustine, De vera religione I, 1; translation in John H. S. Burleigh, trans., Augustine: Earlier Writings, The Library of Christian Classics, vol. VI (Philadelphia: Westminster Press, 1953), 225. Cf., De pace fidei I, 5-6.

88 De vera religione XXXIX, 72; trans. Burleigh, p. 262. Cf., De pace fidei IV, 10-12.

89 De vera religione XLII, 79; trans. Burleigh, p. 266.
} 
There is one God alone to be worshipped, according to Augustine, "and [it is] his Wisdom who makes every wise soul wise." ${ }^{90}$ Augustine concludes De vera religione by urging: "Let our religion bind us to the one omnipotent God, because no creature comes between our minds and him whom we know to be the Father and the Truth, i.e., the inward light whereby we know him. ${ }^{\prime 91}$ As Wilfred Cantwell Smith detects, Augustine barely mentions Christianity in De vera religione, and instead, "[t]he culmination is mystic," ${ }^{92}$ much like the ideal religious dialogue envisioned by Cusanus in the framework of contemplation. ${ }^{93}$ For religio is the bond that unites creatures to the Creator, the Truth and inner light of revelation. Smith also reminds us that the non-Augustinian introduction of the post-enlightenment notion of revealed religion into eighteenth-century Europe has led to confusion. ${ }^{94}$ Cusanus, however, as inheritor of ancient and Augustinian contemplative and universal concepts of religion, reminds readers who venture into his conceptual context that God does not reveal religions, but rather, God reveals God's self as the way and means to beatitude and religious concordance: the Word in relation to words, the finite in hierarchical dialectical gradations to the infinite. Cusanus's religion is not one of the many religions, but the religion: the peace of faith for the peace of the cosmos. In Cusanus's all-encompassing vision and conception of one religion in the variety of rites we detect not even a hint of Pascal's matter of the heart, nor Schleiermacher's intuition of the numinous universe. ${ }^{95}$ As Biechler and Bond note, there are indeed pointers to Luther in De pace fidei, regarding religion and justification by faith. ${ }^{96}$ For Cusanus, this peace of faith is bonded to its object: the Word, the dialogical-incarnational and cosmic-hierarchical

$90 \quad$ De vera religione LV, 112; trans. Burleigh, p. 282.

91 De vera religione LV, 113; trans. Burleigh, p. 282.

92 Wilfred Cantwell Smith, The Meaning and End of Religion: A New Approach to the Religious Traditions of Mankind (New York: Mentor Books, 1964), 31.

93 De pace fidei I, 1.

94 Smith, Meaning and End of Religion, 116.

95 Blaise Pascal, Pensées (Brunschvicg, 1897 edition), 277: "Le coeur a ses raisons que la raison ne connaît point; on le sait en mille choses. Je dis que le coeur aime l'être universel naturellement, et soimême naturellement selon qu'il s'y adonne; et il se durcit contre l'un ou l'autre à son choix." In his second speech, Schleiermacher writes: "I entreat you to become familiar with this concept: intuition of the universe. It is the hinge of my whole speech; it is the highest and most universal formula of religion on the basis of which you should be able to find every place in religion, from which you determine its essence and its limits" (Friedrich Schleiermacher, On Religion: Speeches to its Cultured Despisers, trans. and ed. Richard Crouter (Cambridge: Cambridge University Press, 1996), 24).

96 On faith in De pace fidei, see Biechler and Bond's introduction to Nicholas of Cusa on Interreligious Harmony, xxxvi-xlviii. 
Word of God, through which all things are enfolded and unfolded. ${ }^{97}$ Cusanus even peers subtly ahead to a central tenet of Christian theology, reaffirmed in the Lutheran Confessions: the ubiquity of Christ. ${ }^{98}$

\section{Reading the Christology of De pace fidei in Contemporary Christian-Muslim Dialogue}

Given Cusanus's penchant for Christocentric theology and Greek philosophy, his ideas on one religion in the variety of rites are not without criticism. First and foremost, Cusanus had no real exposure to Muslims, ${ }^{99}$ though for a churchman of his time and place he was remarkably well versed on Islam. ${ }^{100}$ Nonetheless, today he would sound naïve in his belief that rational discourse could indeed achieve lasting religious peace between these two great Abrahamic faiths. Secondly, Cusanus may indeed be guilty of the fallacy of equivocation: while the theological subjects may be the same for Christians and Muslims - for example God, Word, prophets - the predicates are nevertheless different. Thirdly, in our fragmented contemporary world, we have, no doubt, lost faith in the power of logical, dialectical thought as envisioned in De pace fidei. Perhaps it never really worked in reality, but only in Plato's and Cusanus's imaginations. Finally, what about the uniqueness of Christ as mediator between the infinite and finite, God and humanity? ${ }^{101}$ For Augustine, this was not to be found in the books of the Platonists. ${ }^{102}$ Cusanus, on the other hand, seems to suggest in De veneratione sapientiae that Wisdom-Word is found everywhere, or at least in all of the great thinkers, pagan and Christian alike. The Cribratio even shows that he found the concept of Wisdom as incarnate in Christ within the Qur'an. Perhaps, in the end, Cusanus conceived of an all-encompassing religion unrecognizable to both Christians and Muslims. We would do well, however, to approach Cusanus through his own words.

\footnotetext{
97 De pace fidei II, 7.

98 Cf., Formula of Concord, Article VIII.

99 See Cusanus's recounting of possible interactions with Muslim converts to Christianity in Cribratio Alkorani, prologus 3 .

100 For example, Cod. Cus. 205 includes Al-Ghazali on philosophy, Lib. De universali philosophia, with notes by Cusanus, and Avicenna's Metaphysics with a note by Cusanus on f. 8ov. Cod. Cus. 108 contains Ketton's translation of the Qur'an, with numerous notes by Cusanus. For the sometimes inaccurate catalogue to Cusa's library in Kues, see: J. Marx, Verzeichnis der Handschriften-Sammlung des Hospitals zu Cues bei Bernkastel a./Mosel (Trier: Druck der Kunst- und Verlagsanstalt Schaar \& Dathe, Komm.-Ges. a. Akt., 1905).

101 John 14:6. Cf., Cusanus, Sermon CLXXXVI; Sermon CCIII.

102 Augustine, Confessions VII, ix, 13-14.
} 
Therefore, it may be hoped that a theological reading of De pace fide $i$ leads to a greater appreciation of Cusanus's thesis of one religion in the variety of rites, as well as an appreciation of his understanding of the peace of faith through the Word of God as metaphysically rooted in Hellenic thought and the plentitude of ancient conciliar Christology.

Cusanus's conception of the connection between heavenly and earthly, or church and world, is located in the transcendent-immanent Christ, who is both divine wisdom (universalist) and the incarnate Word (exclusivist). As demonstrated by Leo's Tome, cited by Cusanus at the outset of Cribratio, what he sought to avoid was schism - the schism of Christianity and Islam, or any schism between reason and revelation, or between the exclusivity and inclusivity of ancient and conciliar Christology. The concordantia is in and through Christ, the Wisdom of God. With this in mind, three general approaches to religion and religious diversity may be formulated: all religions are the same, all religions are different, or religions exist as unity in plurality. From these, Cusanus comes closest to the third option. For Cusanus, religion is one and cosmic in range and effect, yet rites are many and diffuse in practice. Moreover, rites remain distinct and yet wholly part of one religion. Cusanus, therefore, seems to hold universal and exclusive together dialectically, and through an imagined contemplative and conciliar dialogue, discovers a religious synthesis. There are striking similarities here to the fourth- and fifth-century conciliar Christological debates and formulations over holding to one hypostasis/ persona in two distinct but inseparable natures. De pace fidei sometimes accentuates the exclusive character of the Christian faith, while at other times highlights the universal scope of Wisdom through the plethora of religious rites. Yet ultimately, for Cusanus, truth is found in the Word of God, who "is all and in all."103 While, no doubt, this may prove troubling to Christians and Muslims today, it seems to be truer to Cusanus's thought and intentions. By letting Cusanus speak, we might hear that De pace fidei has something to say to the complexities of our multi-religious world. The ongoing work of finding common ground and conversation instead of conflict continues in such landmark efforts as the textually focused A Common Word.

While Cusanus lived in what he conjectured were the last days, he creatively constructed the contemplative dialogue of De pace fidei as a religious synthesis in a world drastically demarcated by belief. Of course, contra Cusanus, the world did not end in the fifteenth century. Against his archetypal meditations on the peace of faith, violence has perpetuated but religion persists. Throughout the vicissitudes of past and present, Cusanus's prayer for

103 De pace fidei II, 7; Colossians 3:11 NRsv. 
religious peace continues to resonate. The fifteenth century, while no stranger to end-time fervor, was in Southern's terms 'a moment of vision' for Christians perceiving Islam. ${ }^{104}$ These visions of peace, however, were soon eclipsed by the realities of war. Today, through a religious dialogue like A Common Word, we perchance glimpse the moment of vision anew. Amidst proponents of apocalyptical clashes of civilizations and religious conflagrations, Cusanus's De pace fidei reminds both Christians and Muslims of their shared philosophical concepts and the recurrent need for respectful and honest conversation. From a Christian perspective, Cusanus maintains the tension between universality and exclusivity inherent in ancient and conciliar Christology. In so doing, he ultimately points to the dialectical and hierarchical cosmic fullness of the hypostases of the Logos. While Christians and Muslims will continue to differ on fundamental points of belief and practice, adherents of both great Abrahamic faiths still pray along with Cusanus for peace. And, for the fifteenth-century theologian Nicholas of Cusa, the common word for peace between Christians and Muslims is none other than Jesus Christ.

104 The title of chapter three of R. W. Southern's now classic lectures, Western Views of Islam in the Middle Ages (Cambridge: Harvard University Press, 1962), 67-109. 